\title{
Capillaria Hhepatica in Mouse (Apodemus flavicollis) from Giresun Province of Turkey
}

Giresun' daki bir Farede (Apodemus flavicollis) Capilaria hepatica

\author{
Bekir Çelebi ${ }^{1}$, Ayşegül Taylan Özkan²,3, Cahit Babür ${ }^{3}$ \\ ${ }^{1}$ Public Health Institution of Turkey, National High Risk Pathogens Reference Laboratory, Ankara, Turkey \\ 2Department of Medical Microbiology, Hitit University Faculty of Medicine, Çorum, Turkey \\ ${ }^{3}$ Public Health Institution of Turkey, National Parasitology Reference Laboratory, Ankara, Turkey
}

\section{ABSTRACT}

Capillaria hepatica is a nematode with worldwide distribution, which can cause parasitic hepatitis both in animals and humans. A mouse (Apodemus flavicollis), trapped in Giresun Province was diagnosed as having capillariasis due to the characteristic eggs found in its liver. This is the first reported case of mouse capillariasis in this part of the country. Due to the fact that capillariasis is a zoonotic disease, humans might be also infested; therefore, further investigations are needed. (Turkiye Parazitol Derg 2014; 38: 208-10)

Key Words: Capillaria hepatica, mice, Turkey

Received: 08.02.2014

Accepted: 31.03 .2014

\section{ÖZET}

Capillaria hepatica hem hayvanlarda hem de insanlarda parazitik hepatite neden olabilen ve tüm dünyada yaygın olarak görülen bir nematoddur. Giresun Ili'nde yakalanan bir farenin (Apodemus flavicollis) karaciğerinde karakteristik yumurtaların bulunmasına bağlı olarak capillariasis tanısı konmuştur. Ülkenin bu bölgesinde fare capillariasisine bağlı bildirilen ilk olgudur. Capillariasisin zoonotik bir hastalık olması nedeniyle insanlar da enfekte olabileceğinden ileri araştırmalar gerekmektedir. (Turkiye Parazitol Derg 2014; 38: 208-10)

Anahtar Sözcükler: Capillaria hepatica, fare, Türkiye

Geliş Tarihi: 08.02.2014

Kabul Tarihi: 31.03.2014

\section{INTRODUCTION}

Capillaria hepatica is a nematode of rodents, which more rarely also parasitize other mammals, including humans. The life cycle of this parasite in mammalians takes approximately 4 weeks. A mammalian host becomes infested by ingesting mature eggs via contaminated water or food. Infective mature ova hatch in the cecum, and the released larva migrates via the wall of the intestine. The larva reaches the liver through the portal vein within 52 hours after infection and grows into the adult form. After reaching maturity within 21 days, the adult mate and the female start with oviposition. Due to the inflammatory processes within the host, adult worms are destroyed within 30-40 days post-infection; however, some eggs remain viable in the hepatic tissue. The eggs are released in the soil when the host animal is eaten by a predator or undergoes natural decomposition after death.

Address for Correspondence / Yazışma Adresi: Dr. Ayşegül Taylan Özkan, Department of Medical Microbiology, Hitit University Faculty of Medicine, Çorum, Turkey. Phone: +90 36422303 00/1947 E-mail: aysegultaylanozkan@yahoo.com DOI:10.5152/tpd.2014.3501

(C) Copyright 2014 Turkish Society for Parasitology - Available online at www.tparazitolderg.org

OTelif hakkı 2014 Türkiye Parazitoloji Derneği - Makale metnine www.tparazitolderg.org web sayfasından ulaşılabilir. 
Eggs become mature in the soil only after they are freed from the liver and exposed to optimal temperature and moisture in the presence of sufficient oxygen within 2-5 weeks (1-3).

In Turkey, cases of Capillaria spp. infection were reported from different regions, especially in wild birds and poultry but also in foxes, roe deer, cats, dogs, and camels (4-9). There is only one study on rats and mice, which were caught in the vicinity of Beytepe village in Ankara. In this study, 2.8\% of animals were infected with Capillaria gastrica (10). Only one human C. hepatica case was reported in 1954 in a 60-year-old male incidentally diagnosed as having capillariasis (1).

This paper presents the first case of $C$. hepatica in a mouse caught in Giresun Province, which is located in the northern part of Turkey.

\section{CASE REPORT}

A mouse (Apodemus flavicollis), which was trapped in Giresun province during a Hantavirus survey, was dissected, and yellowish-white lesions (2-3 $\mathrm{mm}$ in diameter) in liver were observed macroscopically. The liver, chopped into small pieces into petri dishes, was waited in warm water for a few hours and then squeezed. The remaining fluid, fixed in 10\% PBS buffered formalin, was examined $(11,12)$.

Eggs and/or the adult worms of $C$. hepatica were identified microscopically in the grossly yellowish-white lesions (Figure 1-3). The eggs were scattered throughout the liver.

The presence of the parasite was confirmed by morphological identification of the characteristic bipolar plugged eggs, which were oval and had a double-layered, radial, striated outer shell (Figure 1, 2). The length of the immature eggs was between 49 to $57 \mathrm{~mm}$, and their width was 32 to $41 \mathrm{~mm}$.

The adult worms were not intact; however, their uteri were full of un-embryonated characteristic Capillaria eggs (Figure 3).

\section{DISCUSSION}

Giresun Province is located in the western part of the Black Sea $\left(40,07^{\circ} 41,08 \nsubseteq\right.$ north latitude and $37,50^{\circ} 39,12 థ$ east longitude).

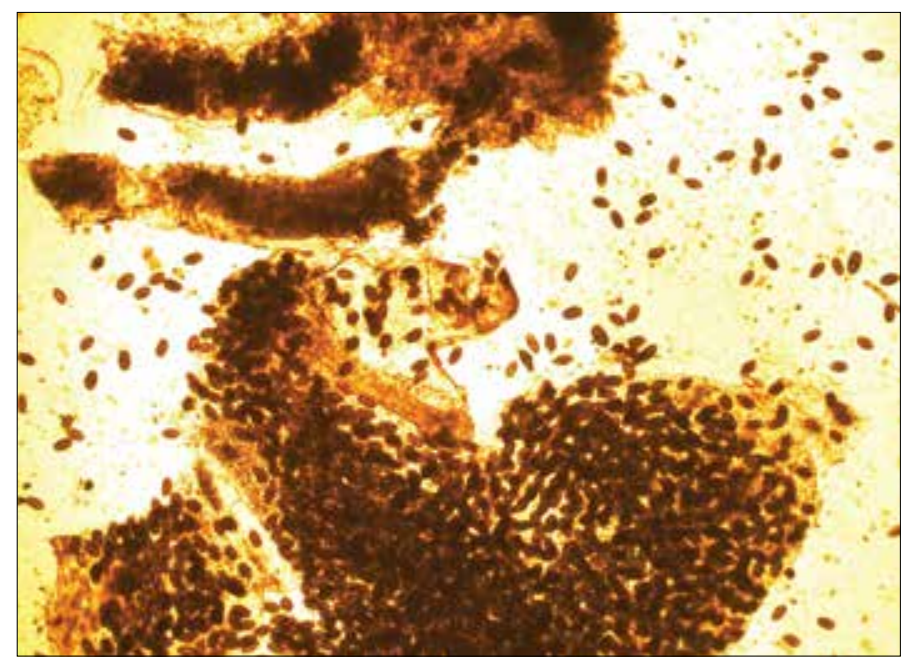

Figure 1. Capillaria hepatica eggs scattered in rat's liver (X10)
The province is surrounded on the northern part by the Black Sea, while on the eastern part lies Trabzon and Gümüşhane, on the south Sivas and Erzincan, east Karabük, and on the western part the province of Ordu. The average altitude is $10 \mathrm{~m}$. Forests are the most important natural habitat, since $34 \%$ of the province is covered with trees. There is close contact between humans and the forest ecosystem, which contains many different rodents, including mice (13).

Capillaria hepatica, which is a nematode of rodents, also has a zoonotic character. In Turkey, different species of this nematode were found in animals, such as wild birds, chicken, fox, cat, dog, deer, and camel $(4-12,14)$. Although none of them was identified as $C$. hepatica, there are some publications showing the existence of Capillaria species near this region-i.e., pheasants and roe deer in Samsun and flounder in Sinop $(8,14,15)$. Cases of rat and mouse infection with Capillaria were reported from Beytepe, Ankara (10); accordingly, in this report, we present for the first time the existence of $C$. hepatica in mouse in this region.

Yellowish-white nodules containing eggs and/or the adult worms, which are characteristic for C. hepatica infections (16), were also seen in our case. In some of the previous publications (1), adult worms could hardly be found in liver biopsies; however, in the present case, female worms with uteri filled with eggs were observed, which could be an indication that the infection was recent. The presence of the parasite was confirmed by identification of the typical bipolar plugged eggs in the liver.

Humans are an accidental host for this disease. Altogether, almost 40 cases of hepatic capillariasis in humans have been reported since 1924 all over the world, and one of them from Turkey was presented by Turhan et al. in 1954 (1). The high rate of infection in animals could be the result of high contamination of the environment, which could also be a source for human infection. Up to $90 \%$ of rats (Rattus norvegicus) were infected with this parasite in Brazil, where the five human cases were reported (17). In a zoo in Vienna, Austria, the high rate of infection of house mice was linked to the seropositivity to Capillaria in two zoo employees (1).

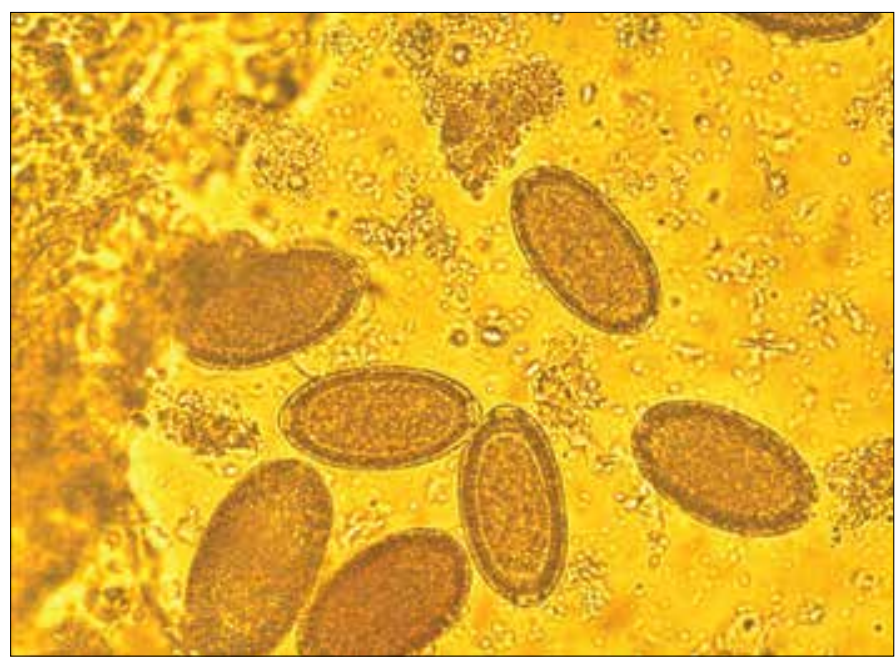

Figure 2. Capillaria hepatica eggs in rat's liver (X40) 


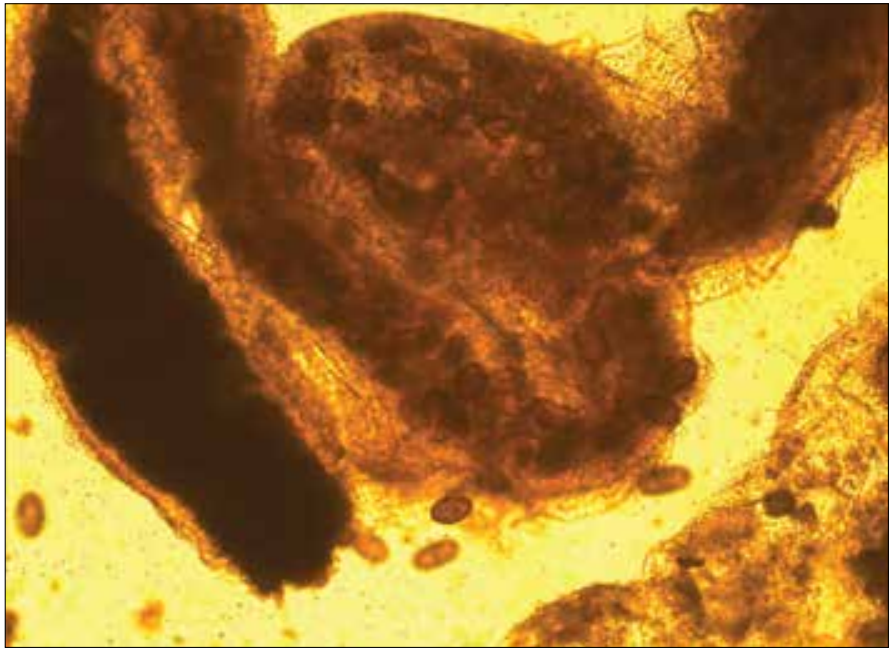

Figure 3. Partially damaged female Capillaria hepatica, whose uterus is full with un-embryonated eggs (X20)

\section{CONCLUSION}

We report for the first time in Giresun Province and also in Turkey the existence of $C$. hepatica in mouse. Further investigation and screening of rodents and other mammals as well as of humans in this region are recommended.

Peer-review: Externally peer-reviewed.

Author Contributions: Concept - A.T.O., B.Ç.; Design - A.T.O.; Supervision - A.T.O.; Materials - C.B., B.Ç.; Data Collection and/ or Processing - C.B., B.Ç.; Analysis and/or Interpretation - A.T.O., B.Ç.; Literature Review - A.T.O., B.Ç.; Writing - A.T.O., B.Ç.; Critical Review - A.T.O.

Acknowledgements: We would like to thank to Assoc. Prof. Dr. Mehmet Ali ÖKTEM from Dokuz Eylül University; Prof. Dr. Ahmet KARATAŞ from Niğde University; Prof. Dr. Mustafa SÖZEN and Dr. Ferhat MATUR from Bülent Ecevit University for their help in field survey of Hantavirus and; Assoc. Prof. Dr. Kosta Y. Mumcuoglu from Hebrew University for his contribution in reviewing the manuscript.

Conflict of Interest: No conflict of interest was declared by the authors.

Financial Disclosure: The authors declared that this case has received no financial support.

Hakem değerlendirmesi: Dış bağımsız.

Yazar Katkıları: Fikir - A.T.O., B.Ç.; Tasarım - A.T.O., B.Ç.; Denetleme - A.T.O.; Malzemeler - C.B., B.Ç.; Veri Toplanması ve/ veya İşlemesi - C.B., B.Ç.; Analiz ve/veya Yorum - A.T.O., B.Ç.; Literatür Taraması - A.T.O., B.Ç.; Yazıyı Yazan - A.T.O., B.Ç.; Eleştirel İnceleme - A.T.O.

Teşekkür: Dokuz Eylül Üniversitesi'nden Prof. Dr. Mehmet Ali ÖKTEM'e; Niğde Üniversitesi'nden Prof. Dr. Ahmet KARATAŞ’a; Bülent Ecevit Üniversitesi'nden Prof. Dr. Mustafa SÖZEN ve Dr. Ferhat MATUR'a Hantavirüs saha araştırmasındaki yardımlarından; Hebrew Üniversitesi'nden Prof. Dr. Kosta Y. MUMCUOĞLU'na makalenin yorumlanmasındaki katkılarından dolayı teşekkür ederiz.

Çıkar Çatışması: Yazarlar çıkar çatışması bildirmemişlerdir.

Finansal Destek: Yazarlar bu olgu için finansal destek almadıklarını beyan etmişlerdir.

\section{REFERENCES}

1. Juncker-Voss M, Prosl H, Lussy H, Enzenberg U, Auer H, Nowotny N. Serological detection of Capillaria hepatica by indirect immunofluorescence assay. J Clin Microbiol 2000; 38: 431-3.

2. Klenzak J, Mattia A, Valenti A, Goldberg J. Hepatic capillariasis in Maine presenting as a hepatic mass. Am J Trop Med Hyg 2005; 72 651-3.

3. Nation PN, Dies KH. Case report: Capillaria hepatica in a horse. Can Vet J 1978; 19: 315-6.

4. Aypak S, Eren H, Bakirci S, Uner S, Simsek E, Boga B, et al. Parasites detected by examination of fecal samples in wrestling camels. Kafkas Univ Vet Fak Derg 2013; 19: 371-4.

5. Kuru BB, Aypak S, Aysul N. Aydın Prevalence of Echinococcus granulosus determined with polymerase chain reaction in dogs in Aydın district. Turkiye Parazitol Derg 2013; 37: 78-83.

6. Burgu A, Doğanay A. Kedilerde üriner capillariose etkenlerinin identifikasyonundaki bazi güçlükler. A U Vet Fak Derg 1986; 33: 38-51.

7. Gııık Y, Kara M, Sarı B, Kılıç K, Arslan MÖ. Intestinal parasites of red foxes (Vulpes vulpes) and their zoonotic importance for humans in Kars Province. Kafkas Univ Vet Fak Derg 2009; 15: 135-40.

8. Gurler AT, Bolukbaş CS, Pekmezci GZ, Umur Ş, Acıcı M. Samsun'da sülünlerde (Phasianus colchicus) nekropsi ve dışkı bakısında saptanan helmintler. Turkiye Parazitol Derg 2012; 36: 222-7. [CrossRef]

9. Köse M, Kırcali Sevimli F, Küpeli Kozan E, Sert Çiçek H. Prevalence of gastrointestinal helminths in chickens in Afyonkarahisar District, Turkey. Kafkas Univ Vet Fak Derg 2009; 15: 411-6.

10. Şahin I. Parasitosis and zoonosis in mice and rats caught in and around Beytepe Village (author's transl). Mikrobiol Bult 1979; 13: 283-90.

11. Kalınbacak F, Burgu A. Türkiye'de yaban bıldırcınlarda (Coturnix coturnix japonica) Cyrnea colini Cram, 1927 (Nematoda, Spiruridae) ve Capillaria sp. (Nematoda, Trichuridae) olgusu. Turkiye Parazitol Derg 2004; 28: 143-5.

12. Yıldırımhan HS, Gürkan E, Altunel FN. Determination of the helminths of wild pigeons (Columba livia Gmelin, 1789 Columbiformes) in the Bursa region. Turkiye Parazitol Derg 2009; 33: 321-6.

13. Karataş A. Türkiye'deki kemirici (Mammalia: Rodentia) türleri. Turk Hij Den Biol Derg 2011; 68: 7-18.

14. Umur Ş, Gürler AT, Beyhan YE, Bölükbaş CS, Açıcı M. Two new nematode species for Turkey helmint fauna in roe deer (Capreolus capreolus), Spiculopteragia spiculoptera (Guschanskaia, 1931) and minor morph S. (Rinadia) mathevossiani (Ruchliadev, 1948). Kafkas Univ Vet Fak Derg 2011; 17: 649-54.

15. Öztürk T, Özer A. Sarıkum Lagün'ünden yakalanan pisi balığının, Platichthyes flesus L., 1758, parazit faunası ve konak faktörlerine göre bulunuşu. J Fisheries Sciences 2008; 2: 403-18.

16. Jeong WI, Do SH, Hong IH, Ji AR, Park JK, et al. Macrophages, myofibroblasts and mast cells in a rat liver infected with Capillaria hepatica. J Vet Sci 2008; 9: 211-3. [CrossRef]

17. Sawamura R, Fernandes MI, Peres LC, Galvão LC, Goldani HA, Jorge SM, et al. Hepatic capillariasis in children: report of 3 cases in Brazil. Am J Trop Med Hyg 1999; 61: 642-7. 